\begin{tabular}{|c|c|}
\hline$\overline{\bar{z}}$ & $\begin{array}{c}\text { International Journal of Current Research } \\
\text { and Academic Review }\end{array}$ \\
\hline & $\begin{array}{c}\text { ISSN: 2347-3215 (Online) Volume } 7 \text { Number } 2 \text { (February-2019) } \\
\text { Journal homepage: http://www.ijcrar.com }\end{array}$ \\
\hline
\end{tabular}

doi: https://doi.org/10.20546/ijcrar.2019.702.001

\title{
Agricultural Credit in Karnataka: A Case study of Primary Agricultural Credit Societies
}

\author{
H.K. Dyavanaika* and S. Mokshapathy
}

Institute of Development Studies, University of Mysore, Manasagangothri, Mysuru-570 006, Karnataka, India

*Corresponding author

\section{Abstract}

In this research paper researchers focused on; agricultural credit in Karnataka; a case study of Primary Agricultural Credit Societies, flow of short term, medium term and long term agriculture credit of PACS, the essentiality of Kisan Credit Card and credit initiatives to Self Groups Schemes for agriculture purpose. agricultural credit supply in many terms such as Institutional and Non-Institutional In a developing economy like ours Agriculture Credit assumes greater significance on account of the fact that it is a critical input to support and sustain crop production as well as farmers. The situation calls for concerted efforts to augment the flow of credit to agriculture, alongside exploring new innovations in product design and methods of delivery, through better use of technology and related processes. This study analyze that flow of agriculture credit from various institution such as NABARD, APEX Bank, DCC Banks, PACS own fund and Commercial Banks are major institutions in supply of agriculture credit and DCC Banks is one having $36.43 \%$ in supply of credit to agriculture in Karnataka. The study reveals that KCC Cards issued to farmers of 24,46,970 has been distributed aims at timely and cost effective manner of agriculture credit and it's good to see that now a day's SHGs targeted to provide agriculture credit and also achieve more than its target. The policy recommended that Govt. has to create awareness among the farmers to avail institutional agriculture credit, availability of loan through KCC Cards and SHGs timely and cost effective manner.
\end{abstract}

\section{Introduction}

Economy of the State is mainly dependent on agriculture as more than $65 \%$ of the total population is engaged in this sector. Credit is an essential sinew for the progress of economic development. In a developing economy like ours Agriculture Credit assumes greater significance on account of the fact that it is a critical input to support and sustain crop production.

\section{Article Info}

Accepted: 22 January 2019

Available Online: 20 February 2019

\section{Keywords}

Agriculture credit, Co-operative Societies, PACS, SHGs, Kisan Credit Cards.
The Co-operative Credit system is the oldest sector of the co-operation movement and consists of short term credit, medium term credit and long term credit structure.

Short Term structure is a three tire structure with Primary Agricultural Credit societies in rural areas, Co-operative Central Banks at the district level and the Apex Bank at the state level.

The Short Term credit structure provides Short Term credit for crop production and Medium Term credit for small developments through Primary Agricultural Co- 
operative Societies. Out of 5352 PACS in state 5149 PACS are functioning and are affiliated to 21 District Cooperative Banks (DCCB) with 680 branches. The Central Banks secure refinance facilities from NABARD through Karnataka state Co-operative Apex Bank. The average lending per farmer is Rs.45008 and average advance per PACS is Rs.180.34 lakhs.

Karnataka state cooperative Agriculture and rural development Bank (KSCARD) at the State level and Primary cooperative agriculture and 177Primary cooperative Agricultural and Rural Development banks at the taluk level cater to the long term credit needs in the two tier credit delivery system. The National bank for Agriculture and Rural Development (NABARD) provides refinance to the Apex bank and KASCARD Bank.

\section{Agricultural loans to farmers at 6\%:}

The State Government has implemented w.e.f. 01-042004 the scheme of providing Agricultural loans at the rate of $6 \%$. The credit goes to the Government for having brought this scheme for the first time in the Country.

The Government has accorded sanction for charging interest at the rate of $6 \%$ on S.T. M.T and L.T. loans availed by the farmers. Accordingly the Co-op. Societies/Institutions have implemented the scheme. The Government reimbursed an average of $5.5 \%$ differential interest to Co-op. Societies. Under this scheme Government has released Rs.60.00 crores and Rs.80.00 crores during the years 2004-05 and 2005-06 respectively.

\section{Agricultural loans to farmers at $4 \%$}

Government has implemented with effect from 01-042006 the scheme of providing Short Term, Medium Term and Long Term loans to farmers and Government will reimburse $7.5 \%$ interest subsidy on the loans issued to farmers through Credit Co-operative Societies. Under this scheme an amount of Rs 153.41 crores has been released by the Govt.

\section{Interest subsidy on agricultural loans disbursed at 3 $\%$}

The scheme of advancing agricultural and allied loans to the farmers at $3 \%$ through Cooperative credit institutions has been implemented from 01-04-2008. The Government is providing interest subsidy at prescribed rate to the concerned institutions. An amount of Rs. 27700.00 lakhs has been earmarked to implement the scheme in the budget for 2010-11 and the entire amount released by Government has been released to $14,76,251$ farmers through concerned cooperative institutions.

\section{Agricultural loans to farmers at 1\%}

Government has implemented with effect from 01-042011 the scheme of providing Short Term agricultural loans to farmers up to 3.00 lakhs and The Short term Agricultural loans which were not due on 31-03-2011. The scheme of lending Medium and long term Agricultural loans up to Rs. 10.00 lakhs at $3 \%$ is continued in this year also. Government has made budget provision of Rs.625.00 crores and released Rs.435.00 crores to implement the scheme.

An amount of Rs. 13100.00 lakhs has been released to 100281 SC beneficiaries under the SCP programme and Rs. 1094.00 lakhs has been released to 77035 ST beneficiaries under TSP programme and $100 \%$ progress achieved in utilizing the fund allotted to SC/ST

\section{Agricultural loans to farmers at 0\% and 1\%}

Government has implemented with effect from 01-042012 the scheme of providing Short Term Agricultural loans to farmers up to Rs. 1.00 lakhs at $0 \%$ interest rate and crop loans above Rs.1 lakh to Rs.3.00 lakhs are continued to be lend at $1 \%$.

The scheme of lending Medium and Long Term Agricultural loans up to Rs. 10.00 lakhs at $3 \%$ is continued for the year 2012-13. Government has made budget provision of Rs.392.04 crores and released Rs 392.03 crores to implement the scheme with effect from 01-04-2013 the Government has increased the 0\% loan limit of the short term agricultural loan from 1 lakh to 2 lakhs and with effect from 01-04-2014 0\% limit of short term Agricultural loan has further increased from 2 lakhs to 3 Lakhs.

\section{Plan for the year 2015-2016}

It is proposed to disburse Rs 10500.00 crores of agricultural loans to 23.50 lakh farmers in the State @ 0\% Upto 3.00 lakhs through Cooperatives for the year 2015 -2016. Medium and long term agricultural loans Upto Rs.3.00 lakhs are being lent at 3\%. 


\section{Objectives of the study}

To study the flow of short term, medium term and long term agriculture credit of PACS.

To study the Kisan Credit Card Scheme and Self Help Groups Schemes in agriculture credit.

\section{Scope and limitations of the study}

Agriculture is playing a vital role in development of India. The agricultural credit supplied by both Institutional and Non-Institutional. Despite in this study only Primary Agricultural Co-operative Societies (PACS) used as Institutional Credit flow to agriculture sector in Karnataka. For the purpose of this study only secondary data has taken for analysis. Data used for Performance of ST, MT and LT Credit Structure in the Karnataka, from 2015-16- to 2017-18, Agricultural Loans disbursement from 01-04-2017 to 31-03-2018, Recovery of loans 2015-16 to 2017 18, Self Help Groups 2015-16 to 2017-18 and so all the limitations of secondary data are found in the study.

\section{Review of literature}

Anil Kumar Soni et al., (2016) they described that the cooperative banking sector is one of the main partners of Indian banking structure, the cooperative banks have more reach to the rural India, through their huge network of credit societies in the institutional credit structure. The cooperative sector has played a key role in the economy of the country and always recognized as an integral part of our national economy. Cooperatives have ideological base, economic objects with social outlook and approach. The cooperative covers almost all cent percent villages in India. The cooperative form of organization is the Ideal Organization for economically weaker sections in the country. According to recent study by World Bank and National Council for Applied Economic Research, the Primary Agriculture Credit Societies (PACS) amount for about 30 percent of micro credit in India. This paper attempts to analyze the role of co-operative bank in agricultural credit.

Ghose and Patel (1991) examined the flow of institutional credit to farm sector and actual status of marginal and small farmers in allocation of institutional credit on the secondary data. They concluded that there was no specific discrimination against marginal and small farmers. Further, they found that the Commercial Banks were given the exclusive role for planning of the service, area approach and the relative shares of the
Cooperative Banks. Commercial Banks in the total agricultural credit generate some management problems for the implementation of the Service Area approach.

Harikesh Maurya (2015) advised that identifies the beneficiaries of co-operative banks' agricultural credit and to assess the impact for bank finances and the borrower-farmers. The impact has measured in terms of the benefits realized by the borrowers. These specific parameters that have been used for the purpose are: land utilization, extent of irrigation, cropping intensity, output pattern, cultural practices, input structure, gross and net farm incomes, employment pattern, saving pattern, and value assets like investment pattern, in addition to the identification and assessment of the benefits realized by the sample participants, an attempt is also made to examine farmers' attitudes.

Harjinder Pal Singh Saluja (2013) in a study entitled "Role of cooperative bank in agricultural credit: A study based on Chhattisgarh", found that the cooperative banking sector is one of the main partners of Indian banking structure, the cooperative banks have more reach to the rural India, through their huge network of credit societies in the institutional credit structure.

\section{Materials and Methods}

This study was mainly focused on the flow of short term, medium term and long term agriculture credit of PACS and the Kisan Credit Card Scheme and Self Help Groups Schemes in agriculture credit in Karnataka. The time series data of PACS on institutional credit in Karnataka to agricultural sector where collected from the following published sources.

The secondary data have been collected from various publications of Government of Karnataka, Department of planning and Co-operation, Bureau of Statistics Karnataka and Other Institutions, NABARD Annual Report and SAHAKARA SINDHU Department of Cooperation Government of Karnataka.

\section{Tools of analysis}

The following tools were employed to analyze the data with reference to selected objectives of this study:

Percentage variation,

Percentage growth,

Simple average method. 


\section{Results and Discussions}

Table 1 describes that agricultural loan disbursement of short term loan accounted to Rs. 10571.88, medium term loan Rs. 848.73 and long term loan Rs. 198.27. New members granted of Rs. 1612.13 among 218290 members and out of which loan to SC/ST member of Rs. 1283.23 Crores among 274678 members.

Table 2 reveals that the funds involved by various institutions in the Short term agricultural loans disbursed through PACS_from 01-04-2017 to 31-03-2018. DCC Banks stands first place in disbursement of short term loan accounted Rs. 3851.62 Crores, NABARD occupy second place in disbursement of loan in Karnataka provided Rs. 3450 Crores and followed by APEX Banks Rs. 3019.19 Crores, Commercial Banks Rs. 197.3 Crores and PACS Own Fund Rs. 53.77 Crores disburse the short term credit to agriculture sector in Karnataka.

Table 3 and figures shows that As on 31-3-2018, During the year 2017-18, the short term (ST), medium term (MT) and long term (LT) loans disbursed by the cooperative credit system in the State was Rs. 10,571.88 crores, Rs. 848.73 crores and Rs. 198.27 crores respectively, thereby achieving progress of $86.06 \%$ as against the annual target.

The comparative position of recovery of short, medium and long term loans under the cooperative credit system in the state for the years from 2015-16 to 2017-18 is presented in the above table. 1.4. It explain that the loan have been recovered during the year 2015-16 of short term loan as 98.33, 86.68 and 37.00 , during the year 2016-17 of medium term loan recovered as $94.12,74.13$ and 40.50, during the year 2017-18 of Long term loan recovered as 91.06, 78.64 and 50.42 from this data the recovery of loan have been decrease in trend due to the farmers are expected waive off of all ST, MT and LT from 2015 to 2018.

\section{Kisan credit cards}

The Kisan Credit Card Scheme introduced in the year 1997 - 1998 aims at providing timely and adequate credit support to the farmers for their cultivation needs in a flexible and cost effective manner.

As on 31.3.2018 since inception out of which 24,46,970 $\mathrm{KCC}$ cards has been distributed from Co-operative
Banks and 24,53,587 farmers are covered under Personnel accident insurance scheme.

\section{Kisan credit card scheme}

\section{Purpose}

KCCOD (KISAN CREDIT CARD OVER DRAFT) To meet the short term credit requirements for

a. cultivation of crops.

b. Post-harvest expenses.

c. Produce marketing loan.

d. Consumption requirements of farmer household.

e. Working capital for maintenance of farm assets and activities allied to agriculture.

2. KCCTL (KISAN CREDIT CARD TERM LOAN) To meet Investment credit requirement for agriculture and allied activities.

\section{Eligibility}

i. Farmers - individual/joint borrowers who are owner cultivators.

ii. Tenant farmers, oral lessees and share croppers.

iii. Self Help Groups (SHGs) or Joint Liability Groups (JLGs) of farmers including tenant farmers, share croppers etc.

\section{Limit}

The limit will be assessed based on scale of finance, anticipated average farm income, repaying capacity.

\section{Nature of facility}

KCCOD - Overdraft.

KCCTL - Term loan.

\section{Margin}

1) For KCCOD - NIL.

2) For investment credit - $10 \%$ to $25 \%$ depending upon the investment.

\section{Maximum repayment period}

KCCOD / KCCTL - Five years. 
Table.1 Agricultural Loans disbursement from 01-04-2017 to 31-03-2018

(Rs. in crores)

\begin{tabular}{|c|c|c|c|c|c|c|c|}
\hline \multirow[t]{2}{*}{ Sl.No } & \multirow[t]{2}{*}{ Particulars } & \multirow[t]{2}{*}{ Number } & \multirow[t]{2}{*}{ Amount } & \multicolumn{2}{|c|}{$\begin{array}{c}\text { Out of which } \\
\text { Loans for New } \\
\text { members } \\
\end{array}$} & \multicolumn{2}{|c|}{$\begin{array}{c}\text { Out of which } \\
\text { Loans to SC/ST } \\
\text { members }\end{array}$} \\
\hline & & & & No & Amt & No & Amt \\
\hline 1 & $\begin{array}{l}\text { Short term } \\
\text { loan }\end{array}$ & 2039201 & 10571.88 & 156636 & 730.54 & 271196 & 1222.84 \\
\hline 2 & $\begin{array}{l}\text { Medium term } \\
\text { loan }\end{array}$ & 58371 & 848.73 & 58371 & 848.73 & 3198 & 46.21 \\
\hline 3 & $\begin{array}{l}\text { Long term } \\
\text { loan }\end{array}$ & 6883 & 198.27 & 3283 & 32.86 & 284 & 13.18 \\
\hline Total & & 2104455 & 11618.88 & 218290 & 1612.13 & 274678 & 1283.23 \\
\hline
\end{tabular}

Sources: SAHAKARA SINDHU, Department of Co-operation, Govt. of Karnataka.

Table.2 The funds involved by various institutions in the Short term agricultural loans disbursed through PACS is as follows

\begin{tabular}{|c|l|r|}
\hline Sl.No & $\begin{array}{c}\text { Name of the } \\
\text { Institution }\end{array}$ & $\begin{array}{c}\text { Funds Involved } \\
\text { (Rs.crores) }\end{array}$ \\
\hline $\mathbf{1}$ & NABARD & $\mathbf{3 4 5 0}$ \\
\hline $\mathbf{2}$ & APEX Bank & $\mathbf{3 0 1 9 . 1 9}$ \\
\hline $\mathbf{3}$ & DCC Banks & $\mathbf{3 8 5 1 . 6 2}$ \\
\hline $\mathbf{4}$ & PACS Own fund & $\mathbf{5 3 . 7 7}$ \\
\hline $\mathbf{5}$ & Commercial Bank & $\mathbf{1 9 7 . 3}$ \\
\hline \multicolumn{2}{|c|}{ Total } & $\mathbf{1 0 , 5 7 1 . 8 8}$ \\
\hline
\end{tabular}

Sources: SAHAKARA SINDHU, Department of Co-operative, Govt. of Karnataka.

The funds involved by various institutions in the Short term agricultural loans disbursed through PACS

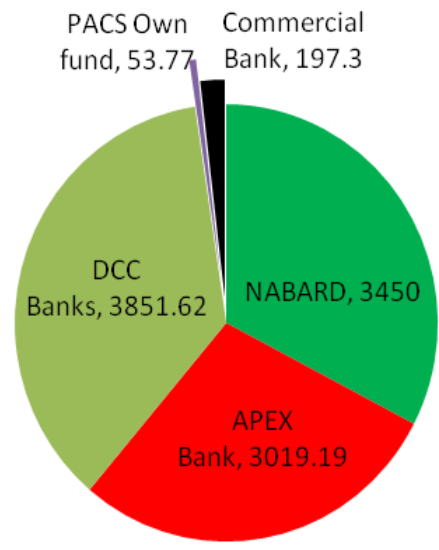


Table.3 Performance of Short Term, Medium Term and Long Term Credit Structure in the Karnataka

\begin{tabular}{|r|r|r|r|r|r|r|r|r|r|}
\hline \multirow{2}{*}{ Year } & \multicolumn{2}{|c|}{ Short term } & \multicolumn{2}{c|}{ Medium term } & \multicolumn{2}{|c|}{ Long term } & \multicolumn{2}{|c|}{ Total } \\
\cline { 2 - 10 } & Target & Achievement & Target & Achievement & Target & Achievement & Target & Achievement \\
$(\boldsymbol{\%})$ & 262.5 & 10638 & 10871.92 & $\mathbf{1 0 2 . 1 9}$ \\
\hline $\mathbf{2 0 1 5 - 1 6}$ & 10000 & 10235.63 & 400 & 373.79 & 238 & 640.41 & 12600 & 11902.19 & $\mathbf{9 4 . 4 6}$ \\
\hline $\mathbf{2 0 1 6 - 1 7}$ & 11000 & 10769 & 1000 & 692.78 & 600 & 198.27 & 13500 & 11618.88 & $\mathbf{8 6 . 0 6}$ \\
\hline $\mathbf{2 0 1 7}-18$ & 12000 & 10571.88 & 1000 & 848.73 & 500 & &
\end{tabular}

Sources: SAHAKARA SINDHU, Department of Co-operation, Govt. of Karnataka.

Performance of short Term Credit structure (Rs. in Crores)

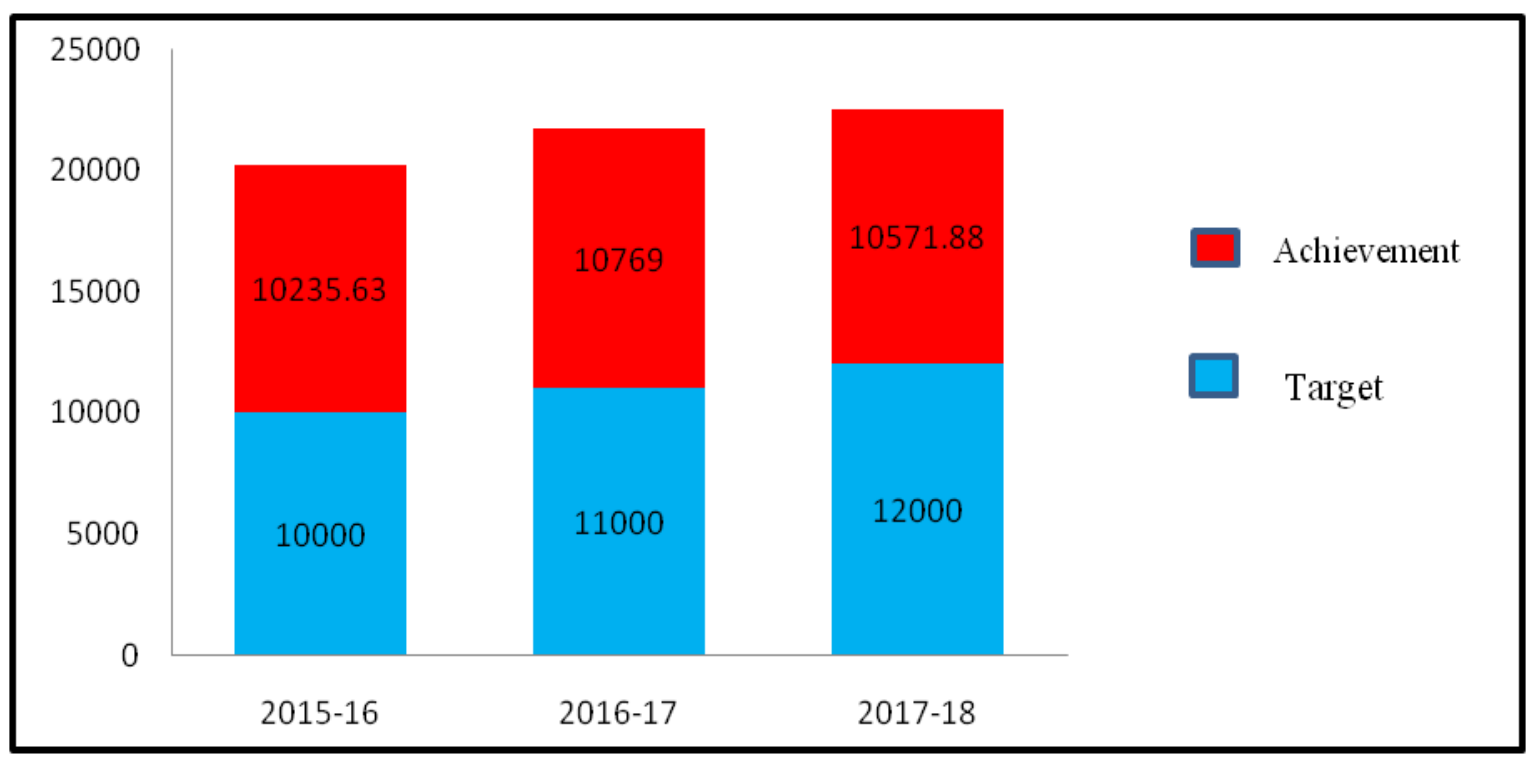

Performance of Medium Term credit structure (Rs. in Crores)

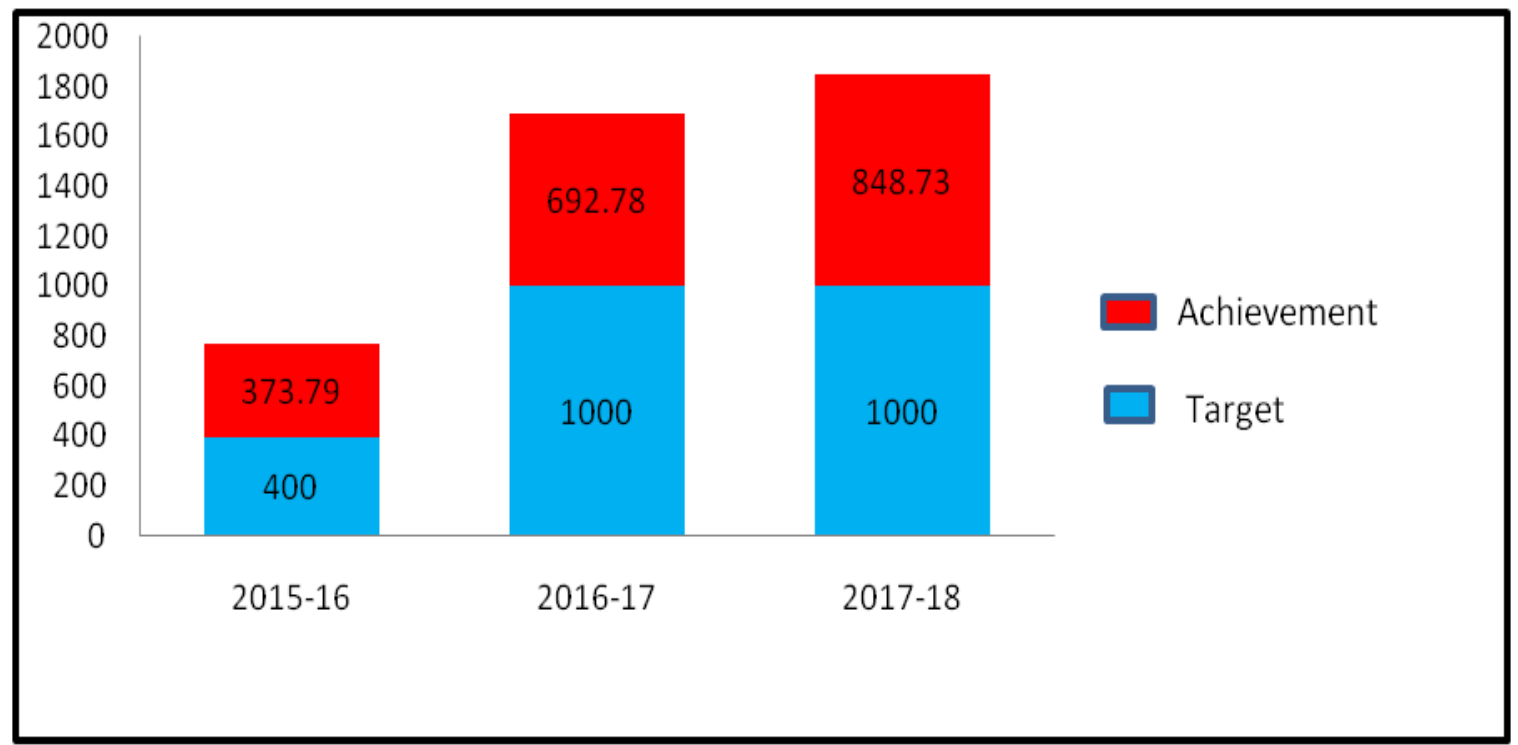


Performance of short Long Term structure (Rs. in Crores)

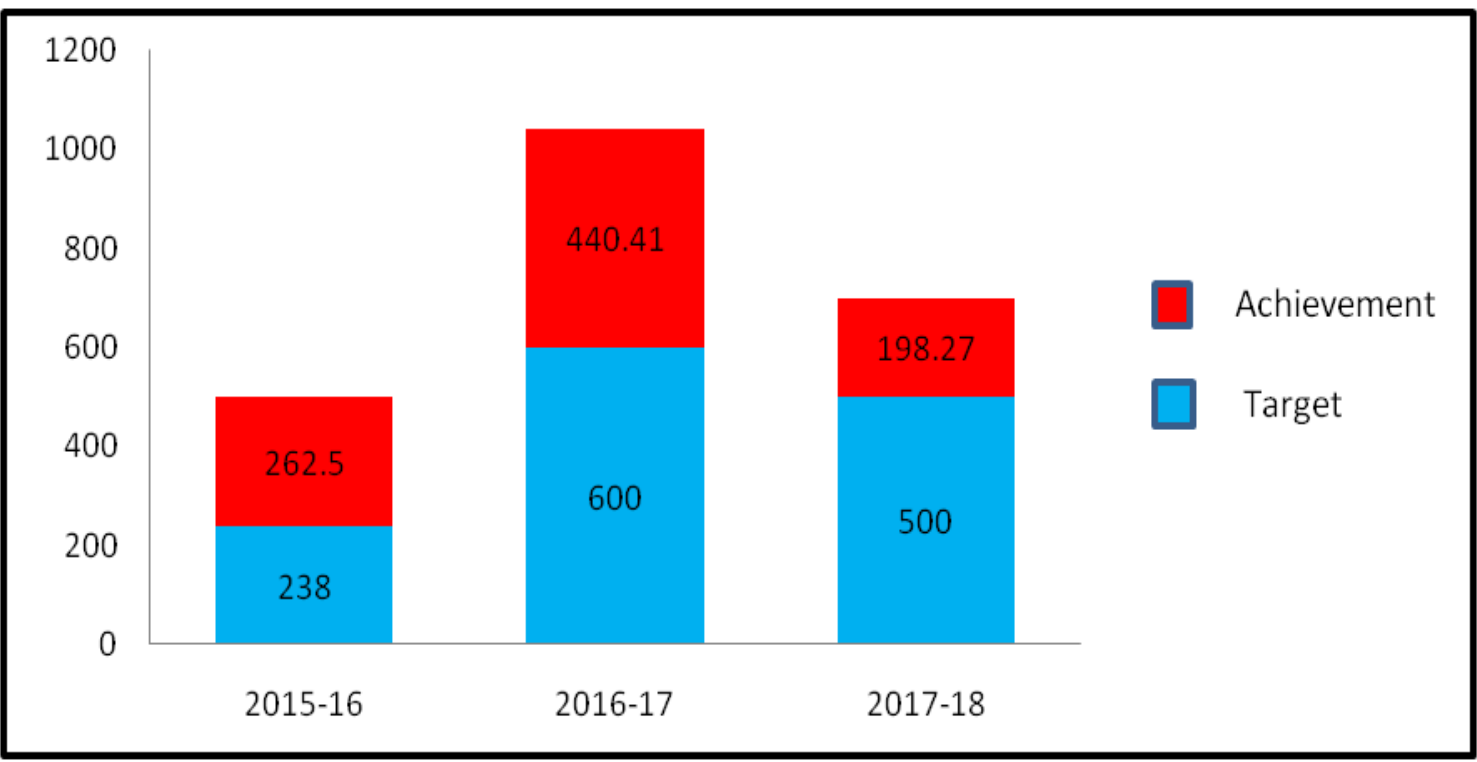

Total disbursment of agriculture loan during last 3 years( achievement as against target in (\%)

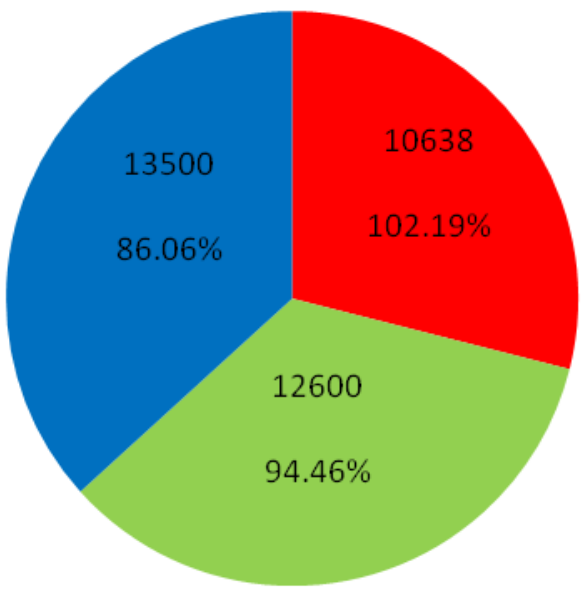

Table.4 Recovery of loans

\begin{tabular}{|c|c|c|c|c|c|c|c|c|c|c|c|c|}
\hline \multirow[b]{2}{*}{ Year } & \multicolumn{4}{|c|}{ Short term loan } & \multicolumn{4}{|c|}{ Medium term loan } & \multicolumn{4}{|c|}{ Long term loan } \\
\hline & Demand & Collection & Balance & $\begin{array}{c}\% \text { of } \\
\text { Recovery }\end{array}$ & Demand & Collection & Balance & $\begin{array}{c}\% \text { of } \\
\text { Recovery }\end{array}$ & Demand & Collection & Balance & $\begin{array}{c}\% \text { of } \\
\text { Recovery }\end{array}$ \\
\hline 2015-16 & 9757.32 & 9594.06 & 163.26 & 98.33 & 210.18 & 182.18 & 28 & 86.68 & 590.69 & 218.58 & 372.11 & 37.00 \\
\hline 2016-17 & 9954.19 & 9368.72 & 585.47 & 94.12 & 427.23 & 316.71 & 110.52 & 74.13 & 638.07 & 258.41 & 379.66 & 40.50 \\
\hline 2017-18 & 10594.3 & 9647.08 & 947.17 & 91.06 & 539.54 & 424.3 & 115.24 & 78.64 & 852.33 & 429.71 & 422.62 & 50.42 \\
\hline
\end{tabular}

Sources: SAHAKARA SINDHU, Department of Co-operation, Govt. of Karnataka 


\section{Recovery in percentage of ST, MT and LT Loan}

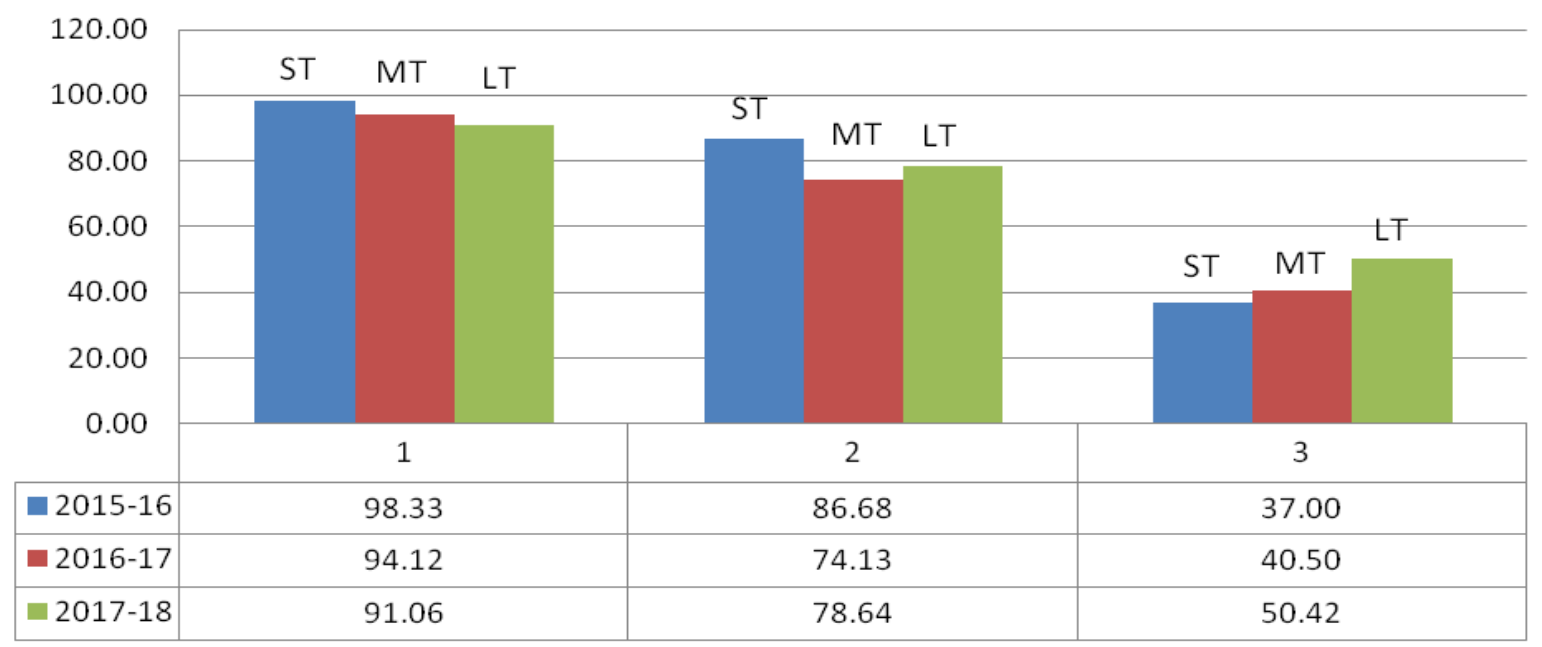

Table.5 Interest subsidy to self help groups

\begin{tabular}{|c|c|c|c|c|c|c|c|c|c|c|c|c|c|c|}
\hline \multirow{3}{*}{ Year } & \multicolumn{2}{|c|}{ Group Formation } & \multicolumn{4}{|c|}{ Fresh Finance } & \multicolumn{4}{|c|}{ Repeat Finance } & \multicolumn{4}{|c|}{ Total Loans } \\
\hline & \multirow{2}{*}{ Target } & \multirow{2}{*}{ Achie } & \multicolumn{2}{|c|}{ Target } & \multicolumn{2}{|c|}{ Achievement } & \multicolumn{2}{|c|}{ Target } & \multicolumn{2}{|c|}{ Achievement } & \multicolumn{2}{|c|}{ Target } & \multicolumn{2}{|c|}{ Achievement } \\
\hline & & & No & Amt & No & Amt & No & $\mathrm{Amt}$ & No & Amt & No & Amt & No & Amt \\
\hline $2015-16$ & 6000 & & $\overline{1723}$ & 111.75 & 9361 & 102.47 & 28277 & 598.25 & 24568 & $\overline{521}$ & 40000 & 710 & 33929 & 624.29 \\
\hline $2016-17$ & 2000 & & 2000 & 130 & 8834 & 169.44 & 32000 & 630 & 24046 & 547.12 & 44000 & 760 & 32880 & 716.56 \\
\hline $2017-18$ & 12000 & 23862 & 9500 & 184 & 13689 & 418.67 & 26500 & 606 & 25083 & 682.75 & 36001 & 790 & 38772 & 101.92 \\
\hline
\end{tabular}

Sources: SAHAKARA SINDHU, Department of Co-operation, Govt. of Karnataka

Table.6 The SLIC has sanctioned the Recapitalization assistance to the PACS as under on 31-3-2010

\begin{tabular}{|c|c|c|c|c|c|c|c|}
\hline \multirow[b]{2}{*}{ Sl.No } & & \multirow{2}{*}{$\begin{array}{l}\text { No of } \\
\text { PACS }\end{array}$} & \multirow[b]{2}{*}{ Category } & \multicolumn{4}{|c|}{ Total Revival package Amount } \\
\hline & & & & $\begin{array}{c}\text { GOI } \\
\text { Share }\end{array}$ & $\begin{array}{c}\text { GOK } \\
\text { Share }\end{array}$ & $\begin{array}{l}\text { PACS } \\
\text { Share }\end{array}$ & Total \\
\hline 1 & First installment & 1834 & A & 139.74 & 39.53 & 23 & 202.27 \\
\hline 2 & Second installment & 1459 & B & 201.62 & 25.97 & 17.84 & 245.43 \\
\hline 3 & Third installment & 960 & $\mathrm{C}$ & 215.17 & 21.22 & 28.47 & 264.86 \\
\hline 4 & Ineligible PACS & 220 & - & 45.6 & 5.17 & 6.54 & 57.31 \\
\hline & Total & 4473 & $\begin{array}{c}\mathbf{A , B}, \mathbf{C}, \mathbf{D} \\
\text { PACS }\end{array}$ & 602.13 & 91.89 & 75.85 & 769.87 \\
\hline
\end{tabular}

Sources: SAHAKARA SINDHU, Department of Co-operation, Govt. of Karnataka. 
Table.7 Progress Achieved By PACS after Implementation of Revival Package

\begin{tabular}{|c|l|r|r|}
\hline \multicolumn{1}{|c|}{ I.No } & \multicolumn{1}{|c|}{ Particulars } & \multicolumn{1}{|c|}{$\begin{array}{c}\text { Pre-implementation } \\
\mathbf{( 3 1 - 0 3 - 2 0 1 0 ) ( 1 - 4 - 2 0 0 9} \\
\text { to 31-3-2010) }\end{array}$} & $\begin{array}{r}\text { post-implementation } \\
\mathbf{( 3 1 - 0 3 - 2 0 1 4 )} \mathbf{( 1 - 4 -} \\
\mathbf{2 0 1 3} \text { to 31-3-2014) }\end{array}$ \\
\hline $\mathbf{1}$ & No of PACS in the state & 4613 & 5270 \\
\hline $\mathbf{2}$ & No Of PACS Selected for BDP & 4403 & 4535 \\
\hline $\mathbf{3}$ & $\begin{array}{l}\text { No of Societies which have attained current } \\
\text { viability }\end{array}$ & 1877 & 4372 \\
\hline $\mathbf{4}$ & $\begin{array}{l}\text { No of Societies which have attained } \\
\text { Sustainable viability }\end{array}$ & 1097 \\
\hline $\mathbf{5}$ & Total Deposits mobilised by PACS & 1869.89 crores & 1495 \\
\hline $\mathbf{6}$ & Total Credit Business of PACS & 4305.98 crores & $\begin{array}{r}5019.31 \mathrm{crores} \\
(+313.65 \mathrm{cr})\end{array}$ \\
\hline $\mathbf{7}$ & Non Credit Business of PACS & 668.58 crores & $1551.44 \mathrm{crores}(-8.28 \mathrm{cr})$ \\
\hline
\end{tabular}

Sources: SAHAKARA SINDHU, Department of Co-operation, Govt. of Karnataka

\section{Repayment schedule}

- 1) KCCOD - On demand (within the repayment period with annual review).

- 2) KCCTL - In Monthly / quarterly / half yearly / yearly installments depending upon the activity undertaken / depending upon the anticipated harvesting and marketing period for the crops which loan is granted.

\section{Security}

- Upto one lakh - Hypothecation of crops.

- Above one lakh - Hypothecation of crops and Collateral of agricultural lands.

\section{Self help groups}

Table 5 indicated the interest subsidy to Self Help Groups and the scheme of advancing loans at interest rate of $4 \%$ through primary agricultural credit societies to Self Help groups (SHGs) in Karnataka has been implemented from 01.04.2007. The differential rate of interest is being reimbursed as interest subsidy by the Government to the co-operative societies. Interest subsidy at the rate of $8.25 \%$ and $7.5 \%$ to PACS and DCC Banks respectively has been provided on loans disbursed during the year 2013-14. Budget allocation of Rs.6262.75lakhs has been provided for the year 2015-16 and the entire provision has been released as interest subsidy to the co-operative institutions. Rs.2089.50 lakhs loan has been disbursed to 75611 SHGs for the year 2016-17. In the year 2017-18, Women SHG groups have been disbursing loans at $0 \%$ up to Rs. 5 lakh during the year 2017-18 Rs. 1101.92 crore of loan has been disbursed to 38772 SHG groups and Rs. 32.00 crore of interest subsidy has been released.

\section{Revival package for short term co-operative credit structure}

In order to strengthen the short term co-operative credit structure in the State, the Govt. of Karnataka has signed the Memorandum of Understanding with Govt. of India and NABARD on 25-03-2008 for implementation of the revival package formulated by the Government of India based on the recommendations of the task force headed by Prof. A. Vaidyanathan. In view of the above, the State level implementation committee (SLIC) under the chairmanship of the principal secretary to the Govt. Finance department has approved Rs.769.87 crores as the amount under this package pertaining to 4474 PACS coming under the jurisdiction of all DCCBs as on 31-32004

The assistance earmarked for 219 PACS which come under ineligible category is Rs.50.77 crores (GOI Rs.45.60 crores and GOK share Rs.5.17 crores). The decision on releasing the above said amount will be taken by SLIC.

The PACS share of Rs.75.85 crores to be adjusted by the PACS after improving the resources using their own capital by adopting Business Development Plan. 
The GOK has made budgetary provision of Rs.91.89 crores towards Revival Package during 2010-11.

For the year 2009-10, the amount of Rs.202.27 crores has been released to 1834 'A' category PACS on March2010 through respective DCCBs, towards the assistance under the package.

For the year 2010-11, the amount of Rs.245.43 crores has been released towards 1459 to 'A' category PACS of Bidar, South Canara and Udupi and the remaining all B and a few 'C category PACS in March-2011 through respective DCCBs and the remaining portion of second installment amount of Rs.264.86 crores has also been released to 960 PACS of the remaining ' $\mathrm{C}$ ' category in April-2011 through respective DCCBs.

Among all DCC Banks, the two weak banks, viz, KCC Bank Ltd., Dharwad and Kolar DCC Bank Ltd., have got Rs.126.81 crores and Rs.69.09 crores respectively under the revival package. As a result of this, these two DCCBs have become currently viable and have complied with Section 11 of the Banking Regulation Act. This recapitalization assistance has been utilized effectively for the strengthening of short term credit structure by adopting the Development Action Plans (DAP) for DCCBs and Business Development Programmes (BDP) for PACS to become economically vibrant and sustainable in 3 years.

In conclusion, the institutional credit has been conceived to play an important role in the agricultural development of India. Agriculture credit supply in many terms such as institutional and non-institutional, institutional credit supply by Schedule Commercial Banks, Co-operative Societies and RRBs, for this study Co-operative Societies selected especially PACS, SHGs and KCCS which are mainly provide short and medium term credit to farmers for crop production. funds involved in supply of institutional credit to agriculture sector in Karnataka such as NABARD occupy of $32.63 \%$, APEX Bank $28.56 \%$, DCC Banks $36.43 \%$, PACS own funds $0.51 \%$ and Commercial Banks $1.87 \%$. The performance of short term, medium term and long term credit structure achieved has been decreased as $100.19 \%$ to $96.46 \%$ and $86.06 \%$ respectively. the recovery of loan during the year from 2015 to 2018 has decrease in trends of $98.38 \%$,

\section{How to cite this article:}

Dyavanaika, H.K. and Mokshapathy, S. 2019. Agricultural Credit in Karnataka: A case study of Primary Agricultural Credit Societies. Int.J.Curr.Res.Aca.Rev. 7(2), 1-10.

doi: https://doi.org/10.20546/ijcrar.2019.702.001
$94.12 \%$ and $91.06 \%$ respectively in short term loan, to decreasing in nature of recovery of loan due to may be crop failure, environmental calamities, not good price in market for their produce and expected waive off of loan, in medium term also has similar kind of trends and in long term credit increasing trends but the percentage of loan recovery is very less when it compared to short term and medium term loan, the reason it could be returns on loan term investment was delayed. Now a day's agricultural credit is providing to SHGs through formation of groups of women's to support them for engage in agriculture sector. During the year 2015 to 2018 the group's formation of SHGs was reached more than the target. The Kisan Credit Cards introduced by NABARD in 1997 aims at providing timely and adequate credit support to farmers for their cultivation timely and cost effective manner, 24,46,970. KCC Cards has been distributed from Co-operative Banks, the problem of KCC Cards success is that many of farmers doesn't aware of availability and use of KCC Cards. The policy recommended that the Govt. have to come out with farmer's friendly agricultural credit initiatives which are helps to sustain the agriculture and farmers.

\section{References}

Acharya, S. S. (2005), Agricultural Marketing And Rural Credit: Status, Issues And Reform Agenda.

Anil Keshav Jadhan. (2015). Agricultural Credit in India: Status and Problems. 2320 - 8341.

Bhosale. (1988). Over dues of Co-operative loans - A Case Study in Maharashtra Land Bank. J. 26(45).

Gulati A. and Bhatia S. (2000). Institutional Credit to Indian Agriculture.

SAHAKARA SINDHU. Department of Co-operation, Govt. of Karnataka.

Singh, Koshta and Chandrakar. (2004). Availability, Utilization and Repayment of Crop Loan; A case study of rice growers under district central Cooperative Bank, Rajpur J. Co-operative Manage. 39(1) 57-64. 